\title{
Assessment of genotoxicity of Ssanghwa-tang, an herbal formula, by using bacterial reverse mutation, chromosome aberration, and in vivo micronucleus tests
}

\author{
Ji-Hye Jang ${ }^{1}$, Chang-Seob Seo ${ }^{1}$, Mee-Young Lee ${ }^{2}$, Hyeun-Kyoo Shin ${ }^{1}$, Su-Cheol Han ${ }^{3}$, Hyekyung $\mathrm{Ha}^{1 *}$ \\ ${ }^{1} \mathrm{KM}$ Science Research Division, Korea Institute of Oriental Medicine \\ ${ }^{2} \mathrm{KM}$ Convergence Research Division, Korea Institute of Oriental Medicine \\ ${ }^{3}$ Jeonbuk Branch Institute, Korea Institute of Toxicology
}

\begin{abstract}
Objectives: Ssanghwa-tang (SHT) is a traditional herbal formula comprising nine medicinal herbs, and it is used for reducing fatigue in Korea. SHT exerts various effects such as anti-inflammatory, antioxidant, and anti-aging activities, and protection against acute hepatotoxicity. However, the genotoxicity of SHT has not yet been established.

Methods: Ten components were identified in SHT water extract by using high-performance liquid chromatography analysis. We assessed the genotoxicity of SHT by using bacterial reverse mutation (Ames test), chromosome aberration, and in vivo micronucleus tests.

Results: The contents of paeoniflorin, glycyrrhizin, and liquiritin apioside in SHT were 15.57, 6.94, and $3.48 \mathrm{mg} / \mathrm{g}$ extract, respectively. SHT did not increase the revertant colonies of Salmonella typhimurium and Escherichia coli strains in the presence or absence of metabolic activity. Although SHT did not induce structurally abnormal chromosomes in Chinese hamster lung (CHL) cells in the presence of metabolic activity, the number of structurally aberrated chromosomes increased dose-dependently in the absence of metabolic activity. In the in vivo micronucleus test, SHT did not affect the formation of micronuclei compared with the vehicle control.

Conclusions: Genotoxicity of SHT was not observed in the Ames test and in vivo micronucleus test. However, based on the results of chromosome aberration test, it can be presumed that SHT has the potential to induce genotoxicity because it induced structurally abnormal chromosomes in the absence of metabolic activity.
\end{abstract}

$\overline{K e y}$ Words : Ssanghwa-tang, Genotoxicity, Bacterial reverse mutation test, Chromosome aberration test, In vivo micronucleus test

\section{Introduction}

Herbal medicines have been traditionally used for a long time and are now widely used to replace pharmaceutical drugs. The use of herbal medicines for the prevention and treatment of several diseases is expanding rapidly worldwide ${ }^{1)}$. Herbal medicines have long been considered safe. However, no experimental basis has been established to determine the toxicity of traditional herbal medicines ${ }^{2}$. Recently, there have been increasing concerns on various toxicities, such as

\footnotetext{
- Received : 28 January 2021

- Revised : 16 July 2021

- Accepted : 5 November 2021

- Correspondence to : Hyekyung $\mathrm{Ha}$

Herbal Medicine Research Division, Korea Institute of Oriental Medicine

1672 Yuseong-daero, Daejeon 34054, Republic of Korea

Tel : +82-42-868-9513, Fax : +82-42-864-2120, E-mail : hkha@kiom.re.kr
} 
hepatotoxicity and nephrotoxicity, caused by traditional herbal medicines. Therefore, it is necessary to perform experiments to establish the basic safety of various herbal medicines ${ }^{3-7}$.

Ssanghwa-tang (SHT), a traditional herbal formula, has long been used in Korea for the reduction of fatigue caused by colds and for the enhancement of physical strength. Korean pharmaceutical companies produced 39 million bottles of SHT in 2016, and it was in the top 100 over-the-counter drugs ${ }^{8)}$. In recent studies, SHT has been reported to possess many functions, such as protection against acute hepatotoxicity, anti-melanogenic activity, and inhibitory effects on bone loss ${ }^{9-11)}$. It has also been reported to exert analgesic, anti-convulsant, anti-oxidative, anti-aging and anti-inflammatory effects ${ }^{12-14)}$. A recent study showed that SHT exerted anti -inflammatory effects on cigarette smoke-induced airway inflammation by modulation pro-inflammatory cytokines through the matrix metallopeptidase 9 (MMP-9) and extracellular signal-regulated kinase (ERK) signaling pathways ${ }^{15)}$. Although various effects of SHT have been identified, studies on its toxicity have not been performed sufficiently. The acute and repeated oral dose toxicity studies of SHT have been archived in previous reports ${ }^{16,17)}$, but the genotoxicity has not yet been studied.

Genotoxicity test is performed to confirm that there is no possibility of carcinogens or mutagens. Therefore, in this study, we aimed to test the genotoxicity of SHT by using bacterial reverse mutation (Ames test), chromosome aberration, and in vivo micronucleus tests. These tests were performed according to the Organization for Economic Cooperation and Development (OECD) guidelines $^{18-20)}$.

\section{Materials \& Methods}

\section{Chemicals and reagents}

Albiflorin (ALB, 99.8\%), paeoniflorin (PAE, 98.8\%), ferulic acid (FA, 98.0\%), liquiritin (LIQ, 99.6\%), and glycyrrhizin (GLY, 99.0\%) were purchased from Wako Pure Chemical (Osaka, Japan). Cinnamic acid (CA, 99.0\%), coumarin (COU, 99.0\%), and 5-(hydroxy-methyl)furfural (5-HMF, 99.0\%) were acquired from Merck KGaA (Darmstadt, Germany). Liquiritin apioside (LIQA, 98.0\%) and nodakenin (NOD, 99.5\%) were obtained from Shanghai Sunny Biotech (Shanghai, China) and ChemFaces Biochemical (Wuhan, China), respectively. High-performance liquid chromatography (HPLC)-grade solvents (methanol, acetonitrile and water) were purchased from J.T. Baker (Phillipsburg, NJ). Anhydrous acetic acid (glacial) for HPLC was ACS reagent grade and purchased from Merck KGaA (Darmstadt, Germany).

\section{Plant materials}

The nine raw materials (Table 1) of SHT decoction were obtained from Kwangmyungdang Medicinal Herbs (Ulsan, Korea) in October 2016, and identified by Dr. Goya Choi of the Korea Institute of Oriental Medicine (KIOM). The voucher specimens (2016-KE21-1- KE21-9) have been stored at KIOM.

\section{Preparation of Ssanghwa-tang water extract}

To obtain the SHT decoction extract, the nine raw materials described in Table 1 were mixed 


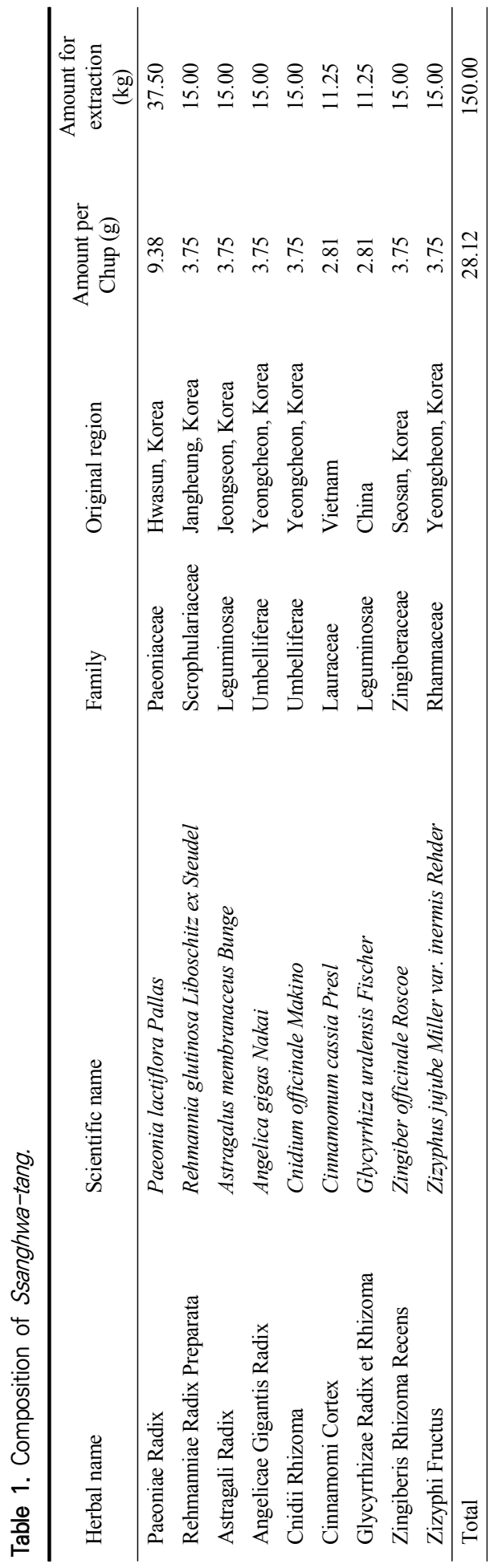




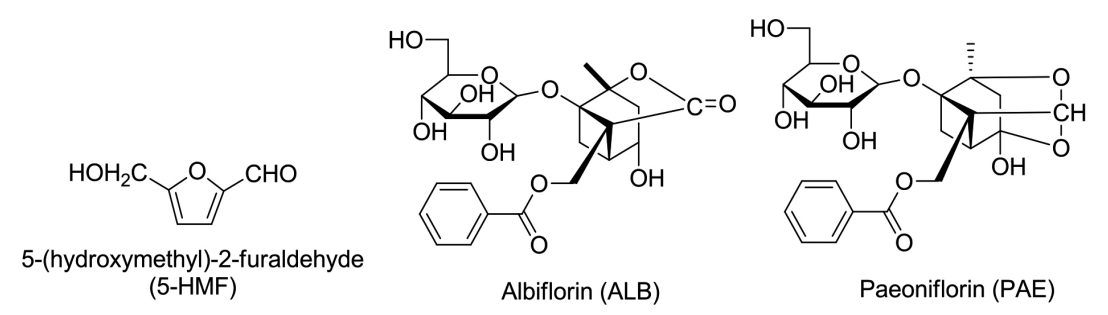

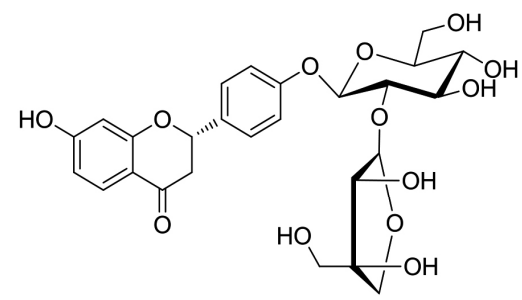

Liquiritin apioside (LIQA)

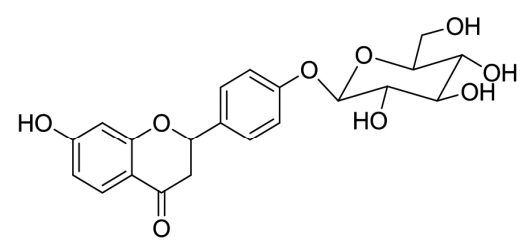

Liquiritin (LIQ)<smiles>CCOc1ccc(/C=C/C(=O)O)cc1OC</smiles><smiles>O=c1ccc2ccccc2o1</smiles>

Coumarin (COU)

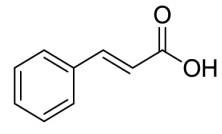

Cinnamic acid (CA)
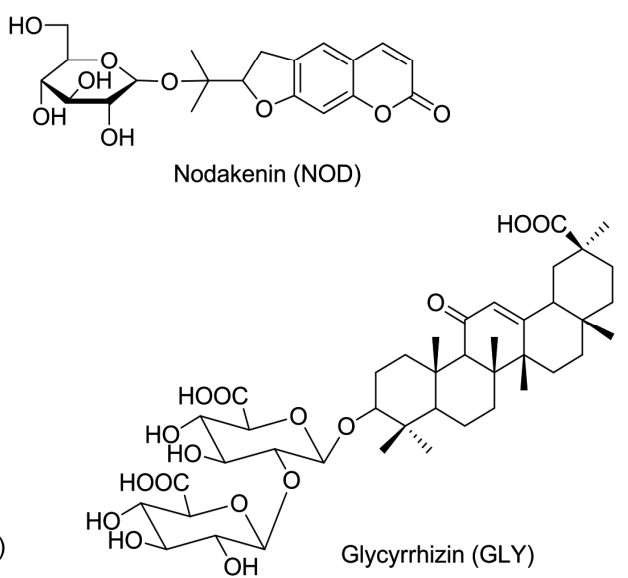

Fig. 1. Chemical structures of the ten marker components in Ssanghwa-tang.

and extracted with distilled water (DW, 1,500 L) at $80^{\circ} \mathrm{C}$ for $2 \mathrm{~h}$ using the reflux method in Sungil Bioex Co., Ltd. (Hwaseong, Korea). The liquid extract was spray-dried to obtained powdered extract of $39.0 \mathrm{~kg}$ (extraction yield: $26.0 \%$ ).

\section{HPLC analysis of Ssanghwa-tang decoction}

Analysis of the 10 marker components (Fig. 1),
ALB, PAE, FA, LIQ, GLY, CA, COU, 5-HMF, NOD, and LIQA, in Ssanghwa-tang was conducted using the Shimadzu Prominence LC-20A series HPLC system (Kyoto, Japan) equipped with a photodiode array (PDA) detector and LCsolution (Version 1.24, SP1, Kyoto, Japan) for measurement and processing of chromatographic data. The 10 components were separated on a Phenomenex Gemini $\mathrm{C}_{18}$ column $(250 \times 4.6 \mathrm{~mm}, 5 \mu \mathrm{m}$ particle 
size, Torrance, CA, USA) at $40^{\circ} \mathrm{C}$. The mobile phases were $1.0 \%(\mathrm{v} / \mathrm{v})$ acetic acid in DW (A) and $1.0 \%$ acetic acid in acetonitrile (B). The gradient flow conditions were as follows: $5-60 \%$ B for $0-40 \mathrm{~min}, 60-100 \% \mathrm{~B}$ for $40-45 \mathrm{~min}$, $100 \% \mathrm{~B}$ for $45-50 \mathrm{~min}$, and $100-5 \% \mathrm{~B}$ for $50-55$ min. The analysis was performed at a flow rate of $1.0 \mathrm{~mL} / \mathrm{min}$ and an injection volume of $10 \mu \mathrm{L}$.

\section{Preparation of S9 mixture}

Many materials may induce mutagenicity after metabolism, even if they are not mutagenic before metabolism in the body. To confirm metabolism-induced mutagenicity, in vitro genotoxicity tests were performed by adding metabolic activation system extracted from the liver of rat. The S9 mixture was prepared by mixing the exogenous metabolizing system (S9 fraction) and cofactor. The S9 fraction was obtained from Molecular Toxicology, Inc. (Boone, NC, USA). The final concentration of cofactors was $8 \mu \mathrm{M} \mathrm{MgCl}_{2}, 33 \mu \mathrm{M} \mathrm{KCl}, 5 \mu \mathrm{M}$ glucose- 6 -phosphate, $4 \mu \mathrm{M}$ nicotinamide adenine dinucleotide phosphate (NADPH), $4 \mu \mathrm{M}$ nicotinamide adenine dinucleotide (NADH), and $100 \mu \mathrm{M}$ sodium phosphate buffer.

\section{Bacterial reverse mutation test (Ames test)}

The Ames test was carried out according to OECD guideline ${ }^{18)}$. The experiment was performed by the method of Maron and Ames ${ }^{21)}$. Histidine -requiring Salmonella typhimurium strains TA98, TA100, TA1535, and TA1537, and the tryptophan -requiring Escherichia coli strain WP2uvrA are known to be sensitive to mutagens and are commonly used in bacterial mutagenicity studies. All strains were obtained from Molecular Toxicology, Inc. (Boone, NC, USA). SHT was dissolved in DW and the maximum treated concentration was $5000 \mu \mathrm{g} /$ plate, as determined by OECD guidelines. Each strain was treated at concentrations of $0,1250,2500$, and $5000 \mu$ $\mathrm{g} /$ plate in the presence or absence of $\mathrm{S} 9$ mix. Sodium azide (SA), 2-nitrofluorene (2-NF), 9-aminoacridine (9-AA), 4-nitroquinoline $\mathrm{N}$-oxide (4NQO), 2-aminoanthracene (2-AA), and benzo (a)pyrene (BP) were respectively used as positive controls. The results are presented as the mean of the number of revertant colonies that occurred at each concentration three times on each plate with the standard deviation (mean $\pm \mathrm{SD}$ ).

\section{Chromosome aberration test}

The chromosome aberration test was conducted in accordance with OECD guideline ${ }^{19)}$, using the method described previously, with minor modifications ${ }^{22-24)}$. Chinese hamster lung (CHL) cells were obtained from the American Type Culture Collection (Manassas, VA, USA). The number of chromosomes in CHL cells was 25 and the doubling time was approximately $15 \mathrm{~h}$. The cells were cultured at $37^{\circ} \mathrm{C}$ in a $5 \% \mathrm{CO}_{2}$ atmosphere in minimum essential medium containing $10 \%$ fetal bovine serum, $2.2 \mathrm{~g} / \mathrm{L}$ of sodium bicarbonate, $2 \mathrm{mM}$ of L-glutamine, $100 \mu$ $\mathrm{g} / \mathrm{mL}$ of streptomycin sulfate and 100 units $/ \mathrm{mL}$ of penicillin $\mathrm{G} \cdot \mathrm{Na}$. The concentration of SHT was determined based on solubility and cytotoxicity in a preliminary range-finding study. SHT $5000 \mu$ $\mathrm{g} / \mathrm{ml}$ was used as the highest concentration and serially diluted twofold to a final concentration of 
$19.53 \mu \mathrm{g} / \mathrm{mL}$. The cells were treated with SHT in the presence $(+\mathrm{S})$ and absence $(-\mathrm{S})$ of S-9 mix. The relative population doubling (RPD) was calculated and used as an index of cell proliferation. In the presence of S9 mixture, the concentrations of SHT were 2600, 4000, and $5000 \mu \mathrm{g} / \mathrm{mL}$ for $6 \mathrm{~h}$. In the absence of $\mathrm{S} 9$ mixture, the concentration of SHT was 1000 , 2600, 3800, and $4000 \mu \mathrm{g} / \mathrm{mL}$ and 1000,2000 , 2600, and $2800 \mu \mathrm{g} / \mathrm{mL}$ for 6 and $22 \mathrm{~h}$, respectively. After completion of treatment with SHT, the cells were washed with $\mathrm{Ca}^{++}$and $\mathrm{Mg}^{++}$ free Dulbecco's phosphate buffered saline (CMF D-PBS) and fresh medium was added. SHT, positive control, and vehicle control (DW) were treated for $6 \mathrm{~h}$ with or without S9 mixture, and $22 \mathrm{~h}$ without S9 mixture. Ethyl methanesulfonate (EMS) was used as a positive control in the absence of S9 mixture, and cyclophosphamide monohydrate (CPA) was used as a positive control in the presence of S9 mixture. After incubation, the cells were fixed in fixation solution (methanol:glacial acetic acid $=3: 1, \mathrm{v} / \mathrm{v}$ ) for $20 \mathrm{~min}$ at $4^{\circ} \mathrm{C}$ and replaced with fresh fixation solution after centrifugation at $1000 \mathrm{rpm}$ for 5 min. The fixed cells were dropped on slides and stained with $3 \%(\mathrm{v} / \mathrm{v})$ Giemsa solution prepared with Gurr buffer. The chromosomal aberrations were differdentiated and counted according to the 'Atlas of chromosome aberration by chemicals (JEMS-MMS, 1988) ${ }^{25)}$.

\section{In vivo micronucleus test}

The in vivo micronucleus test was performed according to OECD guideline ${ }^{20)}$. Six-week-old male ICR specific-pathogen-free mice were obtained from Orient Co., Ltd. (Seongnam, Korea). The mice were housed 3 per cage and maintained at a temperature of $22 \pm 3^{\circ} \mathrm{C}$, relative humidity of $40-70 \%, 12 \mathrm{~h}$ light/dark cycle, light intensity of 150-300 Lux, and air ventilation frequency of 10-20 times $/ \mathrm{h}$. The highest SHT concentration was set at $2000 \mathrm{mg} / \mathrm{kg}$, and SHT was orally administered for 2 days at concentrations of 500,1000, and $2000 \mathrm{mg} / \mathrm{kg}$, respectively. CPA (Sigma-Aldrich, USA) was used as a positive control. It was intraperitoneally administered at $70 \mathrm{mg} / \mathrm{kg}$. After $23 \mathrm{~h}$ from the final administration, the mice were sacrificed by $\mathrm{CO}_{2}$ asphyxiation, and bone marrow cells were separated and stained with $5 \%(\mathrm{v} / \mathrm{v})$ Giemsa solution ${ }^{26}$. Circular and oval bodies showing the same staining pattern as the nuclei of surrounding nucleated cells and with size ranging from $1 / 5^{-1 / 20} 0^{\text {th }}$ of the diameter of the cell were counted as micronucleus (MN). The number of micronucleated polychromatic erythrocytes (MNPCEs) among 2000 polychromatic erythrocytes (PCEs) per individual was measured and expressed as the induced frequency of micronucleus. The ratio of PCEs/[PCEs + normochromatic erythrocytes (NCEs)] was measured by counting 500 erythrocytes regardless of micronucleus.

The in vivo micronucleus test protocol was approved by the Institutional Animal Care and Use Committee of Korea institute of Toxicology (approval number: 1706-0244).

\section{Results}

\section{Marker components of SHT}

In the present study, an optimized HPLC-PDA 

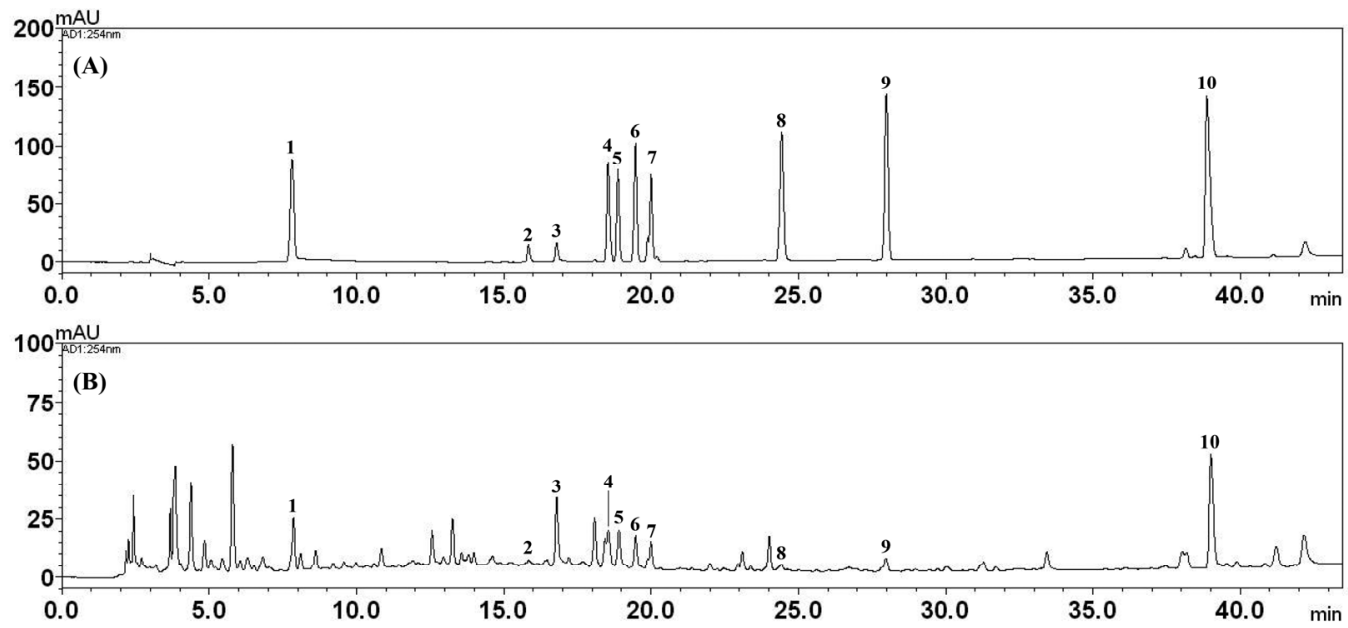

Fig. 2. Representative HPLC chromatogram of the standard mixture (A) and Ssanghwa-tang decoction (B) at $254 \mathrm{~nm}$. 5-HMF (1), ALB (2), PAE (3), LIQA (4), LIQ (5), FA (6), NOD (7), CA (8), COU (9), and GLY (10).

method was successfully applied for the quantitative analysis of the 10 main components in SHT. All the components were separated within $45 \mathrm{~min}$. Representative, HPLC chromatograms of the standard mixtures and SHT sample are shown in Fig. 2. For the quantitative analysis of each compound, ultraviolet absorbance was monitored at the following wavelengths: $230 \mathrm{~nm}$ for ALB and PAE; $254 \mathrm{~nm}$ for GLY; $275 \mathrm{~nm}$ for LIQA,
LIQ, COU, and CA; $280 \mathrm{~nm}$ for 5-HMF; $320 \mathrm{~nm}$ for FA; and $335 \mathrm{~nm}$ for NOD, respectively. The quantity of the 10 marker components in SHT sample was in the range of $0.09-15.57 \mathrm{mg} / \mathrm{g}$ of the extract (Table 2).

\section{Ames test}

In the S. typhimurium strains TA98, TA100, TA1535, and TA1537 and E. coli strain

Table 2. Amounts of the Ten Marker Components in Ssanghwa-tang Determined by HPLC $(n=3)$.

\begin{tabular}{|c|c|c|c|c|}
\hline Compound & Mean (mg/extract g) & $\mathrm{SD}\left(\times 10^{-1}\right)$ & RSD (\%) & Source \\
\hline 5-HMF & 0.94 & 0.03 & 0.34 & R. glutinosa \\
\hline ALB & 1.65 & 0.18 & 1.12 & P. lactiflora \\
\hline PAE & 15.57 & 1.15 & 0.74 & P. lactiflora \\
\hline LIQA & 3.48 & 0.35 & 1.02 & G. uralensis \\
\hline LIQ & 0.87 & 0.19 & 2.14 & G. uralensis \\
\hline FA & 0.50 & 0.09 & 1.85 & C. officinale \\
\hline NOD & 1.85 & 0.17 & 0.92 & A. gigas \\
\hline $\mathrm{COU}$ & 0.15 & 0.02 & 1.20 & C. cassia \\
\hline $\mathrm{CA}$ & 0.09 & 0.01 & 0.81 & C. cassia \\
\hline GLY & 6.94 & 0.046 & 0.66 & G. uralensis \\
\hline
\end{tabular}


WP2uvrA, no reverse mutation was observed in any concentration $(1250,2500$, and $5000 \mu \mathrm{g} / \mathrm{mL})$ groups treated with SHT in the presence or absence of metabolic activation (Table 3). The positive controls significantly increased the number of revertant colonies, indicating that the test was valid. This result showed that SHT has no mutagenic or carcinogenic potential.

\section{Chromosomal aberration test}

In the preliminary dose range-finding study, no cytotoxicity was observed when CHL cells were

Table 3. Results of Bacterial Reverse Mutation Test of Ssanghwa-tang in the Presence or Absence Metabolic Activity.

\begin{tabular}{|c|c|c|c|c|c|c|}
\hline \multirow[b]{2}{*}{ Tester Strain } & \multirow[b]{2}{*}{ Chemical Treated } & \multirow{2}{*}{$\begin{array}{l}\text { Concentration } \\
(\mu \mathrm{g} / \text { plate })\end{array}$} & \multicolumn{2}{|c|}{ Without Activation System } & \multicolumn{2}{|c|}{ With Activation system $^{\mathrm{a}}$} \\
\hline & & & \multicolumn{2}{|c|}{$\begin{array}{l}\text { Revertant Colonies/plate (Mean } \pm \text { SD) } \\
\text { [Fold-increases }]^{\mathrm{b}}\end{array}$} & \multicolumn{2}{|c|}{$\begin{array}{l}\text { Revertant Colonies/plate }(\text { Mean } \pm \text { SD) } \\
\text { [Fold-increases] }\end{array}$} \\
\hline \multirow[t]{4}{*}{ TA100 } & Vehicle Test Item & 0 & $129 \pm 11$ & & $139 \pm 4$ & \\
\hline & & 1250 & $133 \pm 4$ & {$[1.0]$} & $151 \pm 18$ & [1.1] \\
\hline & & 2500 & $136 \pm 5$ & {$[1.1]$} & $145 \pm 7$ & {$[1.0]$} \\
\hline & & 5000 & $177 \pm 21$ & {$[1.4]$} & $164 \pm 3$ & {$[1.2]$} \\
\hline \multirow[t]{4}{*}{ TA1535 } & Vehicle Test Item & 0 & $14 \pm 2$ & . & $12 \pm 3$ & 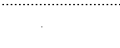 \\
\hline & & 1250 & $14 \pm 3$ & {$[1.0]$} & $11 \pm 1$ & {$[1.0]$} \\
\hline & & 2500 & $12 \pm 3$ & {$[0.9]$} & $11 \pm 2$ & {$[1.0]$} \\
\hline & & 5000 & $15 \pm 5$ & {$[1.1]$} & $13 \pm 1$ & {$[1.1]$} \\
\hline \multirow[t]{4}{*}{ TA98 } & Vehicle Test Item & 0 & $25 \pm 2$ & & $38 \pm 1$ & \\
\hline & & 1250 & $27 \pm 7$ & {$[1.1]$} & $31 \pm 6$ & {$[0.8]$} \\
\hline & & 2500 & $25 \pm 4$ & {$[1.0]$} & $36 \pm 7$ & [0.9] \\
\hline & & 5000 & $24 \pm 3$ & {$[1.0]$} & $33 \pm 7$ & [0.9] \\
\hline \multirow[t]{4}{*}{ TA1537 } & Vehicle Test Item & 0 & $8 \pm 2$ & 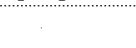 & $13 \pm 3$ & 1 \\
\hline & & 1250 & $10 \pm 4$ & {$[1.2]$} & $11 \pm 2$ & [0.9] \\
\hline & & 2500 & $8 \pm 2$ & {$[1.0]$} & $13 \pm 3$ & {$[1.0]$} \\
\hline & & 5000 & $8 \pm 2$ & {$[1.0]$} & $13 \pm 1$ & {$[1.0]$} \\
\hline \multirow[t]{4}{*}{ WP2uvrA } & Vehicle Test Item & 0 & $19 \pm 2$ & & $23 \pm 2$ & \\
\hline & & 1250 & $20 \pm 2$ & {$[1.1]$} & $21 \pm 1$ & {$[0.9]$} \\
\hline & & 2500 & $20 \pm 3$ & {$[1.1]$} & $23 \pm 3$ & {$[1.0]$} \\
\hline & & 5000 & $18 \pm 2$ & {$[1.0]$} & $20 \pm 2$ & {$[0.9]$} \\
\hline \multicolumn{2}{|c|}{ Positive Controls } & 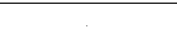 & 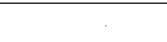 & 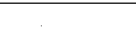 & 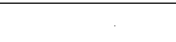 & ? \\
\hline \multirow[t]{2}{*}{ TA100 } & SA & 0.5 & $301 \pm 8$ & {$[2.3]$} & - & - \\
\hline & $\mathrm{BP}$ & 2 & - & - & $660 \pm 59$ & {$[4.7]$} \\
\hline \multirow[t]{2}{*}{ TA1535 } & SA & 0.5 & $199 \pm 17$ & {$[14.5]$} & - & - \\
\hline & 2-AA & 2 & $12 \pm 2$ & {$[0.9]$} & $216 \pm 18$ & {$[18.5]$} \\
\hline \multirow[t]{2}{*}{ TA98 } & $2-N F$ & 2 & $236 \pm 11$ & {$[9.6]$} & - & - \\
\hline & $\mathrm{BP}$ & 2 & $21 \pm 4$ & {$[0.9]$} & $195 \pm 17$ & {$[5.1]$} \\
\hline \multirow[t]{2}{*}{ TA1537 } & 9-AA & 50 & $194 \pm 39$ & {$[24.2]$} & - & - \\
\hline & $\mathrm{BP}$ & 2 & - & - & $77 \pm 4$ & {$[5.9]$} \\
\hline \multirow[t]{2}{*}{ WP2uvrA } & $4 \mathrm{NQO}$ & 1 & $179 \pm 14$ & {$[9.6]$} & - & - \\
\hline & 2-AA & 4 & - & - & $64 \pm 11$ & {$[2.8]$} \\
\hline
\end{tabular}

${ }^{a}$ Metabolic activation system containing $5 \% \mathrm{v} / \mathrm{v}$ of $\mathrm{S} 9$ fraction

${ }^{b}$ No. of revertant colonies of treated plate/No. of revertant colonies of vehicle control plate 
treated with SHT for $6 \mathrm{~h}$ in the presence of metabolic activity. In the absence of metabolic activity, treatment with SHT at a concentration of $3800 \mu \mathrm{g} / \mathrm{mL}$ for $6 \mathrm{~h}$ and $2600 \mu \mathrm{g} / \mathrm{mL}$ for $22 \mathrm{~h}$ resulted in approximately $50 \%$ cytotoxicity (6-S, RPD 51\%; 22-S, RPD 50\%, Supplementary Table 1 and 2). Turbidity was observed at a concentration greater than $1250 \mu \mathrm{g} / \mathrm{mL}$ in all conditions. In the presence of metabolic activity $(+\mathrm{S})$, SHT showed no significant increases in the numerical aberrant metaphase cells and frequency of metaphases with structural aberration compared with the vehicle control. In the absence of metabolic activity, there were significant increases in the frequency of metaphases with structural aberration depending on the concentration of SHT and duration (6 or $22 \mathrm{~h}$ ) compared with the vehicle control (Table 4). There was no observable increase the number of aberrant metaphase cells. The positive controls significantly increased the frequency of metaphases with structural aberration, suggesting that the test was valid.

Table 4. Results of Chromosomal Aberration Test and Relative Population Doubling of Ssanghwa-tang in the Presence or Absence of Metabolic Activation System.

\begin{tabular}{|c|c|c|c|c|c|}
\hline $\begin{array}{l}\text { Concentration } \\
(\mu \mathrm{g} / \mathrm{mL})\end{array}$ & Times (hours) ${ }^{\mathrm{a}}$ & $\begin{array}{l}\text { Mean Aberrant } \\
\text { Metaphases }^{b}\end{array}$ & $\begin{array}{l}\text { Mean Total } \\
\text { Aberrations }\end{array}$ & $\begin{array}{c}\text { Mean of } \\
\text { PP+ER }\end{array}$ & RPD (\%) \\
\hline \multicolumn{6}{|c|}{$6 \mathrm{~h}$ treatment $(+\mathrm{S} 9)$} \\
\hline 0 & $6-18$ & $1.0 / 0.0$ & $1.5 / 1.0$ & $1.0+0.0$ & 100 \\
\hline $2600^{\# \&}$ & $6-18$ & $0.0 / 0.0$ & $1.5 / 1.5$ & $0.0+0.0$ & 115 \\
\hline $4000^{\# \&}$ & $6-18$ & $2.0 / 0.5$ & $0.5 /-0.5$ & $0.5+0.0$ & 110 \\
\hline $5000^{\# \&}$ & $6-18$ & $0.5 / 0.0$ & $0.5 / 0.5$ & $0.0+0.0$ & 98 \\
\hline CPA (6) & $6-18$ & $22.5 / 20.0^{* *}$ & $31.0 / 26.5$ & $0.0+0.0$ & 60 \\
\hline \multicolumn{6}{|c|}{$6 \mathrm{~h}$ treatment $(-\mathrm{S} 9)$} \\
\hline 0 & $6-18$ & $1.5 / 0.0$ & $1.5 / 0.0$ & $0.0+0.0$ & 100 \\
\hline 1000 & $6-18$ & $0.0 / 0.0$ & $0.0 / 0.0$ & $0.0+0.0$ & 105 \\
\hline $2600^{\# \&}$ & $6-18$ & $1.5 / 1.5$ & $1.5 / 1.5$ & $0.0+0.0$ & 71 \\
\hline $3800^{\# \&}$ & $6-18$ & $15.0 / 13.5^{* * \$}$ & $26.5 / 24.0$ & $0.0+0.0$ & 47 \\
\hline $4000^{\# \&}$ & $6-18$ & & Not counted & & 39 \\
\hline EMS (800) & & $18.0 / 18.0^{* *}$ & $19.5 / 19.5$ & $0.5+0.0$ & 79 \\
\hline \multicolumn{6}{|c|}{$22 \mathrm{~h}$ treatment (-S9) } \\
\hline 0 & $22-2$ & $1.0 / 0.0$ & $1.0 / 0.0$ & $0.5+0.0$ & 100 \\
\hline 1000 & $22-2$ & $1.0 / 0.0$ & $1.0 / 0.0$ & $0.0+0.0$ & 100 \\
\hline $2000^{\# \&}$ & $22-2$ & $5.5 / 4.0^{*}$ & $8.5 / 6.5$ & $0.5+0.5$ & 72 \\
\hline $2600^{\# \&}$ & $22-2$ & $8.0 / 6.5^{* * \$}$ & $14.0 / 11.0$ & $0.0+0.0$ & 47 \\
\hline $2800^{\# \&}$ & $22-2$ & & Not counted & & 34 \\
\hline EMS (600) & $22-2$ & $20.5 / 19.5^{* *}$ & $22.5 / 21.5$ & $0.0+0.0$ & 67 \\
\hline \multicolumn{6}{|c|}{$\begin{array}{l}\text { Abbreviations: PP, polyploid; ER, endoreduplication; +S9, treated S9 mixture; }-\mathrm{S} 9 \text {, tre } \\
\text { CPA, cyclophosphamide monohydrate; EMS, ethyl methanesulfonate } \\
\text { \# Visible turbidity of test item was observed at the beginning of the treatment. } \\
\text { \& Visible turbidity of test item was observed at the end of the treatment. } \\
\text { "* Significantly different from the control at } \mathrm{P}<0.05 \text { or } \mathrm{P}<0.01 \text {. } \\
\text { \$ Significantly from Cochran-Armitage trend test at } \mathrm{P}<0.01 \text {. } \\
\text { a Treatment time-recovery time. }\end{array}$} \\
\hline
\end{tabular}




\section{Micronucleus test}

Body weight showed no significant changes in mice administered SHT compared with that in mice administered vehicle control (Supplementary Fig. 1). Moreover, there were no deaths and adverse clinical signs associated with SHT in mice but also no significant increase in the number of MNPCEs and ratio of PCEs/(PCEs + NCEs) at any dose of SHT (Table 5). This test was appropriated because the number of MNPCEs and ratio of PCEs/(PCEs+NCEs) increased in the CPA-treated group, which was a positive control.

\section{Discussion}

In traditional medicine, medicinal herbs have been used for centuries. In recent years, its use has been increasing as an alternative or supplement to counter the limitations of modern medicines. Consumers expect herbal medicines to be more user-friendly and safer than conventional drugs such as synthetic chemicals because these originate from nature and have many clinical applications. However, some herbal medicines adverse events. We investigated such medicines to establish safety data for widely used herbal formulas in Korea. In previous studies, we have reported the acute and sub-acute toxicity of SHT in rats. There was no death or any adverse clinical signs at the highest dose of SHT (2000 $\mathrm{mg} / \mathrm{kg}$ ) in both male and female rats. In the 4-week repeated oral administration toxicity study of SHT, no adverse signs were observed at the dose $2000 \mathrm{mg} / \mathrm{kg}$, while minor changes were observed at the highest dose of $5000 \mathrm{mg} / \mathrm{kg}$. In the present study, the genotoxicity of SHT was estimated by bacterial reverse mutation, in vitro chromosomal aberration and in vivo micronucleus formation tests. The maximum dose of SHT for the micronucleus formation test in mice was 2000 $\mathrm{mg} / \mathrm{kg}$, which converts to a human equivalent dose of $9,756 \mathrm{mg} / 60 \mathrm{~kg}$ adult ${ }^{27)}$. In humans, the dose of 1 Chup of SHT is $28.12 \mathrm{~g}$ as a herbal mixture before extraction (Table 1), and when the extraction yield $(26.0 \%)$ is reflected, it corresponds to $7,311 \mathrm{mg}$ as an extract powder.

Genotoxicity includes mutagenicity and

Table 5. Incidence of in vivo Micronucleated Polychromatic Erythrocytes in the Bone Marrow of Mice Administered with Ssanghwa-tang.

\begin{tabular}{cccc}
\hline \multirow{2}{*}{$\begin{array}{c}\text { Treatment } \\
(\mathrm{mg} / \mathrm{kg})\end{array}$} & No. of animals & MNPCEs $^{\mathrm{a}}$ & ${\text { PECs } /(\mathrm{PCEs}+\mathrm{NCEs})^{\mathrm{b}}}^{n}$ \\
\hline 0 & 3 & $4.00 \pm 1.73$ & $0.52 \pm 0.06$ \\
500 & 3 & $2.67 \pm 0.58$ & $0.49 \pm 0.06$ \\
1000 & 3 & $1.67 \pm 0.58$ & $0.48 \pm 0.02$ \\
2000 & 3 & $4.00 \pm 1.73$ & $0.55 \pm 0.03$ \\
CPA $(70)$ & 3 & $105.33 \pm 21.83$ & $0.52 \pm 0.05$ \\
\hline
\end{tabular}

Abbreviation: MNPCEs, micronucleated polychromatic erythrocytes; PCEs, polychromatic erythrocytes; NCEs, normochromatic erythrocytes; CPA, cyclophosphamide monohydrate.

${ }^{a} 2000$ polychromatic erythrocytes were examined per animal.

${ }^{b} 500$ erythrocytes were examined per animal.

contain toxic ingredients that cause serious carcinogenicity according to DNA damage. The 
Ames test is a bacterial reverse mutation assay that can be performed in a short period to confirm whether a substance has the potential to cause gene mutations through genetic damage ${ }^{28)}$. The in vitro mammalian chromosome aberration test was conducted to detect the structural chromosomal aberrations ${ }^{29}$. The in vivo micronucleus test is a method to confirm genotoxicity by detecting chemical substance-induced micronucleus. Micronuclei are generated by chromosome aberrations, defects of the cell repair system, and accumulation of DNA damage. The formation of micronucleus induced by substances with genotoxicity can lead to cell death or cancer ${ }^{30}$.

In the present study, SHT did not cause reverse mutagenesis in all five bacterial strains, nor did it induce micronucleus formation in mice. In contrast, in CHL cells, chromosomal abnormalities were induced by more than $1000 \mu \mathrm{g} / \mathrm{mL}$ of SHT. In a previous study, Paeoniae Radix, Rehmanniae Radix Preparata, Angelica Gigantis Radix, Cnidii Rhizoma, and Cinnamomi Cortex showed negative results for the chromosomal aberration test in the absence of metabolic activation system in CHL cells at $100 \mu \mathrm{g} / \mathrm{mL}$ extract concentration. On the other hand, Paeoniae Radix, Angelica Gigantis Radix, and Cnidii Rhizoma in the presence of the metabolic activation system induced chromosomal abnormalities in $9 \%, 7 \%$, and $6 \%$ of the observed cells, respectively ${ }^{31)}$. The conditions that induced chromosomal abnormalities in CHL cells by SHT were the absence of metabolic activation system and more than $1000 \mu \mathrm{g} / \mathrm{mL}$ of SHT. It means that SHT itself, not metabolites of SHT, causes chromosomal abnormalities. Also, when SHT taken at normal dose, a concentration of $1000 \mu$ $\mathrm{g} / \mathrm{mL}$ is considered too high to reach in the body. Chromosomal aberration can be caused by a mechanism related to cytotoxicity even by drugs that do not attack DNA, and it is known that the in vitro chromosomal aberration test has a high possibility of showing 'false positive' by inducing cytotoxicity of the treated $\operatorname{drug}^{32)}$. In addition, there is also a study that confirmed the plasma levels of chemicals which showed negative results in the Ames test and in vivo micronucleus test, but showed positive results in the in vitro chromosomal aberration/micronucleus test. According to the study, when the maximum concentration in plasma (Cmax) of the chemical in the in vivo test was lower than the lowest positive concentration (LPC) of the chemical in the in vitro test, negative results were obtained in the in vivo test $^{33)}$. There is a limitation to this study. It is difficult to confirm that this result alone is indicative of genotoxicity.

\section{Conclusions}

SHT did not cause genotoxicity in the Ames test and in vivo micronucleus test, but it caused chromosomal abnormalities in CHL cells. We suggest that although SHT showed a positive result in the in vitro chromosomal aberration test, 1) because the concentration of SHT inducing positive chromosomal aberration showed about $50 \%$ cytotoxicity in CHL cells, it may be a 'false positive' and 2) because SHT did not induce micronucleation in mice, the Cmax of SHT in mice may be lower than the LPC of SHT in CHL cells. Additional tests such as comet assay should be performed to ensure genotoxicity. 


\section{Conflict of interest}

The authors declare that they have no conflict of interest.

\section{Acknowledgements}

This research was supported by grants of the 'Construction of Scientific Evidence for Herbal Medicine Formulas (K17251)' and 'Construction of Safety and Efficacy for Traditional Herbal Prescriptions of Medicinal Institution (KSN2013310)' projects from the Korea Institute of Oriental Medicine (KIOM), Republic of Korea. We would like to thank the Korea Institute of Toxicology (KIT) for providing animal care facility for the study.

\section{References}

1. World Health Organization (WHO). (2004). WHO guidelines on safety monitoring of herbal medicines in pharmacovigilance systems. Available from: URL: http://www.who.int/ iris/handle/10665/43034/

2. Firenzuoli, F. \& Gori, L. (2007). Herbal medicine today: Clinical and research issues. Evidence Based Complementary and Alternative Medicine, 4(S1), 37-40. https://doi.org/10.1093/ ecam/nem096

3. Wang, J., van der Heijden, R., Spruit, S., Hankermeier, T., Chan, K., van der Greef, J., et al. (2009). Quality and safety of Chinese herbal medicines guided by a systems biology perspective. Journal of Ethnopharmacology, 126(1), 31-41. https://doi.org/10.1016/j.jep. 2009.07.040
4. Asif, M. (2012). A brief study of toxic effects of some medicinal herbs on kidney. Advanced Biomedical Research, 1, 44. https://doi.org/10.4103/2277-9175.100144

5. Ekor, M. (2014). The growing use of herbal medicines: Issues relating to adverse reactions and challenges in monitoring safety. Frontiers in Pharmacology, 4, 177. https://doi.org/10. 3389/fphar.2013.00177

6. Stournaras, E. \& Tziomalos, K. (2015). Herbal medicine-related hepatotoxicity. World Journal of Hepatology, 7(19), 2189-2193. https://doi.org/10.4254/wjh.v7.i19.2189

7. Cho, J. H., Oh, D. S., Hong, S. H., Ko, H., Lee, N. H., Park, S. E., et al. (2017). A nationwide study of the incidence rate of herb-induced liver injury in Korea. Archives of Toxicology, 91(12), 4009-4015. https:/doi.org/ 10.1007/s00204-017-2007-9

8. Korea Pharmaceutical and Bio-Pharma Manufacturers Association (KPBMA). Production achievements for pharmaceuticals, etc. in 2018. Seoul: KPBMA. 2019. Available from: URL:https://www.kpbma.or.kr/attach/2019sus데이터북-웹용.pdf

9. Shim, K. S., Lee, J. H., Ma, C. J., Lee, Y. H., Choi, S. U., Lee, J., et al. (2010). Inhibitory effect of Ssanghwa-tang on bone loss in ovariectomized rats. Animal Cells and Systems, 14(4), 283-289. https://doi.org/10. 1080/19768354.2010.528615

10. Lee, J. H., Yang, M. C., Shim, K. S., Lee, J. H., \& Ma, J. Y. (2011). Protective effect of Ssanghwa-tang fermented by Lactobacillus fermentum against carbon tetrachloride -induced acute hepatotoxicity in rats. African 
Journal of Traditional, Complementary and Alternative Medicine, 8(3), 312-321. https://www.ncbi.nlm.nih.gov/pmc/articles/PM C3252232/pdf/AJT0803-0312.pdf

11. Kim, A., Yim, N. H., Im, M., Jung, Y. P., Liang, C., Cho, W. K., et al. (2013). Ssanghwa-tang, an oriental herbal cocktail, exerts anti-melanogenic activity by suppression of the p38 MAPK and PKA signaling pathways in B16F10 cells. BMC Complementary and Alternative Medicine, 13, 214. https://doi.org/ 10.1186/1472-6882-13-214

12. Kim, I. H. \& Hwang, G. J. (1981). Studies on the anti-inflammatory activities of 'Ssangwha-Tang'. Korean Journal of Pharmacognosy, 12(3), 131-135. https://www.koreascience.or.kr/article/ JAKO198103041198098.pdf

13. Han, D. S., Lee, H. K., \& Cho, H. J. (1983). Analgesic and anticonvulsionary effects of Ssanghwa-Tang. Korean Journal of Pharmacognosy, 14(2), 60-63. https://www.koreascience.or.kr/ article/JAKO198303041203827.pdf

14. Park, J. Y., Hwang, J. G., Yun, J. K., Han, K. H., Do, E. J., Kim, S. O., et al. (2012). Effect of ssanghwa-tang extract on antioxidant and anti-aging enzyme activities. The Korea Journal of Herbology, 27(3), 67-74. https://doi.org/ 10.6116/kjh.2012.27.3.67

15. Ko, J. W., Shin, N. R., Park, S. H., Lee, I. C., Ryu, J. M., Cho, Y.K., et al. (2017). Ssanghwa-Tang, a traditional herbal formula, suppresses cigarette smoke-induced airway inflammation via inhibition of MMP-9 and Erk signaling. Molecular and Cellular Toxicology, 13(3), 295-304. https://doi.org/10. 1007/s13273-017-0033-6
16. Kim, S. J., Lee, M. Y., Shin, I. S., Seo, C. S., Ha, H., Huh, J. I., et al. (2011). Single dose acute toxicity of Ssanghwa-tang in Crl:CD (SD) rats. The Korea Journal of Herbology, 26(2), 39-43. https://doi.org/10. 6116/kjh.2011.26.2.039

17. Yoo, S. R., Ha, H., Lee, M. Y., Shin, H. K., Han, S. C., \& Seo, C. S. (2019). A 4-week repeated oral dose toxicity study of Ssanghwa-tang in Crl:CD Sprague Dawley rats. Evidence Based Complementary and Alternative Medicine, 2019, 2135351. https://doi.org/10.1155/2019/2135351

18. Organization for Economic Cooperation and Develppment (OECD) Guidelines for the Testing of Chemicals. (1997). 'Bacterial reverse mutation test' (OECD TG\#471). Available from: URL: https://www.oecd.org/chemicalsafety/ risk-assessment/1948418.pdf

19. OECD Guidelines for the Testing of Chemicals. (2014). 'In vitro mammalian chromosome aberration test' (OECD TG\#473). Available from: URL:https://ntp.niehs.nih.gov/ iccvam/suppdocs/feddocs/oecd/oecd-tg473-20 14-508.pdf

20. OECD Guidelines for the Testing of Chemicals. (2016). 'Mammalian erythrocyte micronucleus test' (OECD TG\#474). Available from: URL:https://www.oecd-ilibrary.org/docserver/ 9789264264762-en.pdf? expires $=1611031436$ $\& \mathrm{id}=\mathrm{id} \&$ accname $=$ guest $\&$ checksum $=95 \mathrm{E} 219$ EF93374249AE0BAB4C1ED1EA04

21. Maron, D. M. \& Ames, B. N. (1983). Revised methods for the Salmonella mutagenicity test. Mutation Research, 113(3-4), 173-215. https://doi.org/10.1016/0165-1161(83)90010-9 
22. Ishidate, M. Jr., Sofuni, T, \& Yoshikawa, K. (1981). Chromosomal aberration tests in vitro as a primary screening tool for environmental mutagens and/or carcinogens. GANN Monograph on Cancer Research, 27, 95-108.

23. Dean, B. J. (1984). Assays for the detection of chemically-induced chromosome damage in cultured mammalian cells. In: Venitt, S., Parry, J. M., editors. Mutagenicity testing, a practical approach. Washington DC: IRL Press. 1984.

24. Galloway, S. M., Aardema, M. J., Ishidate, M. Jr., Ivett, J. L., Kirkland, D. J., Morita, T., et al. (1994). Report from working group on in vitro tests for chromosomal aberrations. Mutation Research, 312(3), 241-261. https://doi.org/ 10.1016/0165-1161(94)00012-3

25. Japanese Environmental Mutagen Society -Mammalian Mutagenicity Study Group. Atlas of chromosome aberration by chemicals. Tokyo: JEMS-MMS. 1988.

26. Gollapudi, B. \& Kamra, O.P. (1979). Application of a simple giemsa-staining method in the micronucleus test. Mutation Research, 64(1), 45-46. https://doi.org/10. 1016/0165-1161(79)90135-3

27. Van Miert, A. S. J. P. A. M. The use in animals of drugs licensed for human use only. In: Van Miert, A. S. J. P. A. M., Bogaert, M. G. \& Debackere, M., editors. Comparative Veterinary Pharmacology, Toxicology and Therapy. Boston: MTP Press. 1986:489500 .

28. Mortelmans, K. \& Zeiger, E. (2000). The Ames Salmonella/microsome mutagenicity assay. Mutation Research, 455(1-2), 29-60. https://doi.org/10.1016/s0027-5107(00)00064-6

29. Clare, G. The in vitro mammalian chromosome aberration test. In: Parry, J. M. \& Parry, E. M., editors. Genetic toxicology. New York: Springer. 2012:69-91. https://link.springer. com/content/pdf/10.1007\%2F978-1-61779-42 1-6.pdf

30. Luzhna, L., Kathiria, P., \& Kovalchuk, O. (2013). Micronuclei in genotoxicity assessment: from genetics to epigenetics and beyond. Frontiers in Genetics, 4, 131. https://doi.org/ 10.3389/fgene. 2013.00131

31. Kim, D. H., Kim, N. J., Jang, J. B., \& Song, B. Y. (1999). Studies on the effects of herbal medicines on the fetus during pregnancy (II)-Mutagenesis and chromosomal aberration of herbal medicines-. The Journal of Korean Oriental Medicine, 20(2), 121-127. https://doi.org/ www.koreascience.or.kr/article/JAKO1999046 37287678.pdf

32. Hilliard, C. A, Armstrong, M. J., Bradt, C. I., Hill, R. B., Greenwood, S. K., \& Galloway, S. M. (1998). Chromosome aberrations in vitro related to cytotoxicity of nonmutagenic chemicals and metabolic poisons. Environmental and Molecular Mutagenesis, 31, 316-326. https://doi.org/10.1002/(SICI)1098-2280(1998 )31:4<316::AID-EM3>3.0.CO;2-G

33. Yamamura, E., Aruga, C., Muto, S., Baba, N., \& Uno, Y. (2018). Correlation between the results of in vitro and in vivo chromosomal damage tests in consideration of exposure levels of test chemicals. Genes and Environment, 40, 6. https://doi.org/10.1186/s41021-018-0094-3 


\section{ORCID}

Ji-Hye Jang https://orcid.org/0000-0002-3002-8202

Chang-Seob Seo https://orcid.org/0000-0002-8156-446X

Mee-Young Lee https://orcid.org/0000-0001-7337-2460

Hyeun-Kyoo Shin https://orcid.org/0000-0003-2319-6678

Su-Cheol Han https://orcid.org/0000-0003-2006-9788

Hyekyung Ha https://orcid.org/0000-0002-7326-6366 


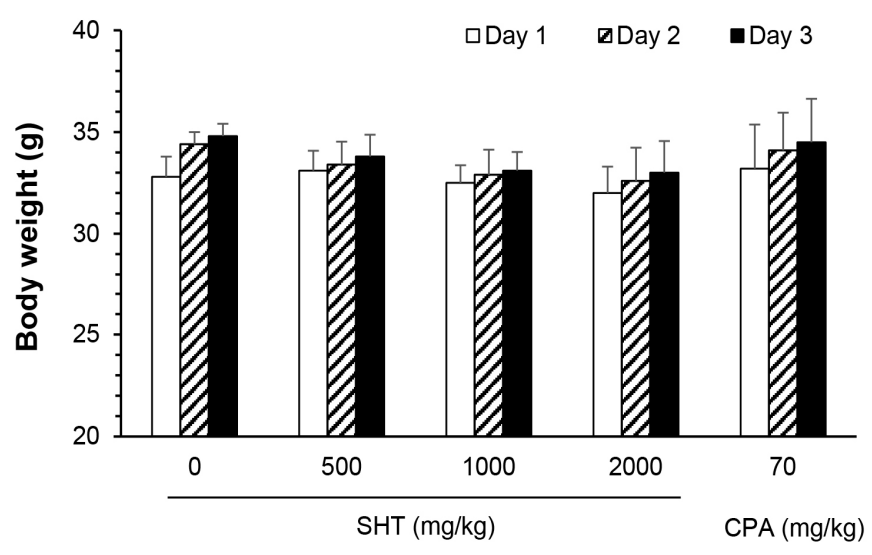

Supplementary Fig. 1. Body weight changes after single administration of Ssanghwa-tang extract at dose level of 0,500, 1000 , and $2000 \mathrm{mg} / \mathrm{kg}$ in male mice. Cyclophosphamide monohydrate (CPA, $70 \mathrm{mg} / \mathrm{kg}$ ) was used as a positive control. Values are expressed as means $\pm S D$ ( $n=3$ per group). 
Supplementary Table 1. Individual relative population doubling (RPD) data from the first study for dose range-finding of Ssanghwa-tang (SHT) in CHL cells

\begin{tabular}{|c|c|c|c|c|c|c|c|c|}
\hline \multirow{2}{*}{\multicolumn{2}{|c|}{$\begin{array}{l}\text { Nominal Conc. of SHT } \\
(\mu \mathrm{g} / \mathrm{mL})\end{array}$}} & \multirow{2}{*}{$\begin{array}{l}\text { Metabolic } \\
\text { Activation } \\
\text { System }\end{array}$} & \multirow{2}{*}{$\begin{array}{l}\text { Times }^{\mathrm{a}} \\
\text { (hours) }\end{array}$} & \multirow{2}{*}{\multicolumn{2}{|c|}{$\begin{array}{c}\text { Cell Counts }^{\mathrm{b}} \\
\text { One Flask/Concentration }\end{array}$}} & \multirow{2}{*}{ Mean } & \multirow{2}{*}{$\mathrm{PD}^{\mathrm{c}}$} & \multirow{2}{*}{$\begin{array}{l}\text { RPD } \\
(\%)^{d}\end{array}$} \\
\hline & & & & & & & & \\
\hline \multicolumn{9}{|c|}{6 -hour treatment $(6+S)$} \\
\hline 0 & & + & $6-18$ & 6905 & 6944 & 6925 & 1.163 & 100 \\
\hline 19.53 & & + & $6-18$ & 6567 & 6425 & 6496 & 1.071 & 92 \\
\hline 39.06 & & + & $6-18$ & 6745 & 6801 & 6773 & 1.131 & 97 \\
\hline 78.13 & & + & $6-18$ & 6920 & 6923 & 6922 & 1.162 & 100 \\
\hline 156.25 & & + & $6-18$ & 7049 & 7000 & 7025 & 1.184 & 102 \\
\hline 312.5 & & + & $6-18$ & 7174 & 7191 & 7183 & 1.216 & 105 \\
\hline 625 & & + & $6-18$ & 7128 & 7084 & 7106 & 1.200 & 103 \\
\hline 1250 & $\# \&$ & + & $6-18$ & 6897 & 6881 & 6889 & 1.156 & 99 \\
\hline 2500 & $\# \&$ & + & $6-18$ & 6565 & 6436 & 6501 & 1.072 & 92 \\
\hline 5000 & $\# \&$ & + & $6-18$ & 5762 & 5711 & 5737 & 0.891 & 77 \\
\hline \multicolumn{9}{|c|}{ 6-hour treatment (6-S) } \\
\hline 0 & & - & $6-18$ & 10014 & 10071 & 10043 & 1.699 & 100 \\
\hline 19.53 & & - & $6-18$ & 10551 & 10607 & 10579 & 1.774 & 104 \\
\hline 39.06 & & - & $6-18$ & 10796 & 10682 & 10739 & 1.796 & 106 \\
\hline 78.13 & & - & $6-18$ & 10678 & 10733 & 10706 & 1.792 & 105 \\
\hline 156.25 & & - & $6-18$ & 10899 & 10820 & 10860 & 1.812 & 107 \\
\hline 312.5 & & - & $6-18$ & 11017 & 10954 & 10986 & 1.829 & 108 \\
\hline 625 & & - & $6-18$ & 11378 & 11276 & 11327 & 1.873 & 110 \\
\hline 1250 & $\# \&$ & - & $6-18$ & 10428 & 10550 & 10489 & 1.762 & 104 \\
\hline 2500 & $\# \&$ & - & $6-18$ & 8463 & 8466 & 8465 & 1.453 & 85 \\
\hline 5000 & $\# \&$ & - & $6-18$ & 4434 & 4430 & 4432 & 0.519 & 31 \\
\hline \multicolumn{9}{|c|}{ 22-hour treatment (22-S) } \\
\hline 0 & & - & $22-2$ & 8461 & 8361 & 8411 & 1.444 & 100 \\
\hline 19.53 & & - & $22-2$ & 8415 & 8283 & 8349 & 1.433 & 99 \\
\hline 39.06 & & - & $22-2$ & 8235 & 8222 & 8229 & 1.412 & 98 \\
\hline 78.13 & & - & $22-2$ & 8633 & 8624 & 8629 & 1.480 & 103 \\
\hline 156.25 & & - & $22-2$ & 8563 & 8562 & 8563 & 1.469 & 102 \\
\hline 312.5 & & - & $22-2$ & 8409 & 8476 & 8443 & 1.449 & 100 \\
\hline 625 & & - & $22-2$ & 8833 & 8884 & 8859 & 1.518 & 105 \\
\hline 1250 & $\# \&$ & - & $22-2$ & 8191 & 8277 & 8234 & 1.413 & 98 \\
\hline 2500 & $\# \&$ & - & $22-2$ & 5757 & 5696 & 5727 & 0.889 & 62 \\
\hline 5000 & $\# \&$ & - & $22-2$ & 3761 & 3630 & 3696 & 0.257 & 18 \\
\hline \multicolumn{4}{|c|}{ Cell number at the treatment } & 3104 & 3081 & 3093 & & \\
\hline
\end{tabular}

\# Visible turbidity of SHT was observed at the beginning of the treatment.

\& Visible turbidity of SHT was observed at the end of the treatment.

a Treatment time-recovery time

${ }^{b}$ Each culture was trypsinized and suspended with $1.0 \mathrm{~mL}$ of $0.05 \%$ trypsin-EDTA and $9.0 \mathrm{~mL}$ of culture medium. The cell suspensions of $0.8 \mathrm{~mL} /$ culture were diluted 25 times with $19.2 \mathrm{~mL}$ of Isoton solution. The cells in $0.5 \mathrm{~mL}$ Isoton solution were counted twice/culture using Coulter Counter ${ }^{\circledR}$ model ZM. Actual number of cells per culture $=$ Mean Count $\times 500$

${ }^{c}$ Population Doubling $=[\log ($ Post-treatment cell number $\div$ Initial cell number $)] \div \log 2$

${ }^{d}$ RPD $=\frac{\text { No. of Population doubling in treated cultures }}{\text { No. of Population doubling in control cultures }} \times 100(\%)$

Abbreviations:

RPD, Relative Population Doubling; +, Presence of metabolic activation system; -, Absence of metabolic activation system 
Supplementary Table 2. Individual relative population doubling (RPD) data from the second study for dose range-finding of Ssanghwa-tang (SHT) in CHL cells

\begin{tabular}{|c|c|c|c|c|c|c|c|c|}
\hline \multicolumn{9}{|c|}{ Study No. P117008 } \\
\hline \multirow{2}{*}{\multicolumn{2}{|c|}{$\begin{array}{l}\text { Nominal Conc. of } \\
\text { SHT }(\mu \mathrm{g} / \mathrm{mL})\end{array}$}} & \multirow{2}{*}{$\begin{array}{l}\text { Metabolic } \\
\text { Activation } \\
\text { System }\end{array}$} & \multirow{2}{*}{$\begin{array}{l}\text { Times }^{\mathrm{a}} \\
\text { (hours) }\end{array}$} & & & \multirow{2}{*}{ Mean } & \multirow{2}{*}{$\mathrm{PD}^{\mathrm{c}}$} & \multirow{2}{*}{$\begin{array}{l}\text { RPD } \\
(\%)^{d}\end{array}$} \\
\hline & & & & \multicolumn{2}{|c|}{ One Flask/Concentration } & & & \\
\hline \multicolumn{9}{|c|}{ 6-hour treatment (6-S) } \\
\hline 0 & & - & $6-18$ & 10130 & 9999 & 10065 & 1.618 & 100 \\
\hline 2600 & $\# \&$ & - & $6-18$ & 7814 & 7981 & 7898 & 1.268 & 78 \\
\hline 2900 & $\# \&$ & - & $6-18$ & 6741 & 6697 & 6719 & 1.035 & 64 \\
\hline 3200 & $\# \&$ & - & $6-18$ & 6305 & 6405 & 6355 & 0.954 & 59 \\
\hline 3500 & $\# \&$ & - & $6-18$ & 5859 & 5762 & 5811 & 0.825 & 51 \\
\hline 3800 & $\# \&$ & - & $6-18$ & 5806 & 5776 & 5791 & 0.820 & 51 \\
\hline 4100 & $\# \&$ & - & $6-18$ & 5429 & 5307 & 5368 & 0.711 & 44 \\
\hline 4400 & $\# \&$ & - & $6-18$ & 5148 & 5032 & 5090 & 0.634 & 39 \\
\hline 4700 & $\# \&$ & - & $6-18$ & 4751 & 4753 & 4752 & 0.535 & 33 \\
\hline 5000 & $\# \&$ & - & $6-18$ & 3604 & 3647 & 3626 & 0.144 & 9 \\
\hline \multicolumn{9}{|c|}{ 22-hour treatment (22-S) } \\
\hline 0 & & - & $22-2$ & 9473 & 9532 & 9503 & 1.535 & 100 \\
\hline 2000 & $\# \&$ & - & $22-2$ & 7109 & 6998 & 7054 & 1.105 & 72 \\
\hline 2600 & $\# \&$ & - & $22-2$ & 5562 & 5589 & 5576 & 0.765 & 50 \\
\hline 2900 & \#\& & - & $22-2$ & 5070 & 5060 & 5065 & 0.627 & 41 \\
\hline 3200 & $\# \&$ & - & $22-2$ & 4635 & 4505 & 4570 & 0.478 & 31 \\
\hline 3500 & $\# \&$ & - & $22-2$ & 4336 & 4280 & 4308 & 0.393 & 26 \\
\hline 3800 & $\# \&$ & - & $22-2$ & 3806 & 3711 & 3759 & 0.196 & 13 \\
\hline 4100 & $\# \&$ & - & $22-2$ & 3745 & 3607 & 3676 & 0.164 & 11 \\
\hline 4400 & $\# \&$ & - & $22-2$ & 3558 & 3466 & 3512 & 0.099 & 6 \\
\hline 4700 & $\# \&$ & - & $22-2$ & 3092 & 3120 & 3106 & -0.079 & -5 \\
\hline \multicolumn{4}{|c|}{ Cell number at the treatment } & 3248 & 3312 & 3280 & & \\
\hline
\end{tabular}

\# Visible turbidity of SHT was observed at the beginning of the treatment.

\& Visible turbidity of SHT was observed at the end of the treatment.

a Treatment time-recovery time

${ }^{b}$ Each culture was trypsinized and suspended with $1.0 \mathrm{~mL}$ of $0.05 \%$ trypsin-EDTA and $9.0 \mathrm{~mL}$ of culture medium. The cell suspensions of $0.8 \mathrm{~mL} /$ culture were diluted 25 times with $19.2 \mathrm{~mL}$ of Isoton solution. The cells in $0.5 \mathrm{~mL}$ Isoton solution were counted twice/culture using Coulter Counter ${ }^{\circledR}$ model ZM. Actual number of cells per culture $=$ Mean Count $\times 500$.

${ }^{c}$ Population Doubling $=[\log ($ Post-treatment cell number $\div$ Initial cell number $)] \div \log 2$

${ }^{d}$ RPD $=\frac{\text { No. of Population doubling in treated cultures }}{\text { No. of Population doubling in control cultures }} \times 100(\%)$

Abbreviations:

RPD, Relative Population Doubling; +, Presence of metabolic activation system; -, Absence of metabolic activation system 